Doi: $\underline{\mathrm{dx} . \text { doi.org/10.17921/2525-5320.2016.52-53 }}$

\title{
RELATO DE UMA EX-ALUNA E DOCENTE SCHOENSTATTIANA
}

Lidia Maria Gonçalves* - UEL

Palavras-chave: Etnografia. Estudo de Caso. Pesquisa Educacional. Pedagogia de Schoenstatt.

\section{INTRODUÇÃO}

Esta publicação tem dois objetivos: o primeiro é contribuir para dar maior visualização, nos meios acadêmicos, à Obra Internacional de Schoenstatt, criada pelo Padre Josef Kentenich, na Alemanha, em 1914; e o segundo é analisar a história e a contemporaneidade do Instituto Mariano, um espeço pedagógico argentino, situado em Oberá, e muito influente no desenvolvimento educacional e cultural não só daquela cidade, como também de toda a província de Misiones, na Argentina. Realizamos um tipo de investigação denominada estudo de caso e recorremos à pesquisa etnográfica.

Apresentar para a comunidade acadêmica perspectivas com relação ao ensino schoenstattiano, investigamos sua singularidade pedagógica, inspirada em seu fundador Padre Kentenich.

\section{MATERIAL E MÉTODOS}

Para entender a dinâmica da prática educativa, na escola objeto dessa pesquisa, o estudo de caso foi ideal, pois é uma estratégia de pesquisa própria para entender um caso particular, levando em conta seu contexto e sua complexidade. Por meio desse trabalho, divulgamos as perspectivas com relação ao ensino schoenstattiano e compartilhamos interpretações geradas pelas observações do cotidiano escolar no Instituto Mariano. Da leitura daquela realidade, extraímos contribuições para a educação argentina, brasileira e mundial, pois, apesar das diferenças na língua e na cultura, na história e na geografia, todo ser humano pode se tornar melhor por meio de uma educação que desenvolva um pensar a formação de personalidades autênticas. 
Observamos, no estudo da prática escolar cotidiana, três dimensões: a institucional/organizacional, a pedagógica/instrucional e a cultural/sociopolítica.

\section{RESULTADOS E DISCUSSÃO}

Apreciamos formas de organizações do trabalho pedagógico, estruturas de poder e decisão, nível de participação dos agentes, disponibilidade de recursos humanos e materiais na escola oberenha. Interpretamos os elementos: objetivos e conteúdos, atividades e material didático, avaliação, comunicação entre os agentes durante 0 encontro entre professor-aluno-conhecimento. E, apreciamos os determinantes macroestruturais da prática educativa desenvolvida no Instituto Mariano.

\section{CONCLUSÃO}

Este estudo conduziu-nos ao conhecimento da identidade da instituição escolar; ao reconhecimento da viabilidade da pedagogia schoenstattiana; à visualização de um contexto histórico-cultural e educacional. Encontramos professores apaixonados e trabalhar com amor é um diferencial enorme.

\section{REFERÊNCIAS}

ANDRÉ, M.E.D.A. Etnografia da prática escolar. Campinas: Papirus, 2004.

CARPETAS HISTÓRICAS DEL INSTITUTO MARIANO. Arquivo das Irmãs de Maria que integraram o Instituto Secular das Irmãs de Maria de Shoenstatt. Oberá-Argentina, de 1949 a 1999 e de 2000 a 2009.

GOFFMAN, E. Manicômios, prisões e conventos. São Paulo: Perspectiva, 2001. 